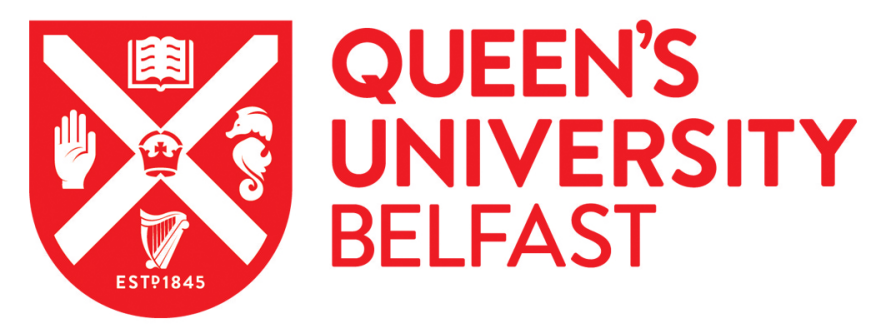

\title{
The Climate of War: Violence, Warfare and Climatic Reductionism
}

Livingstone, D. N. (2015). The Climate of War: Violence, Warfare and Climatic Reductionism. Wiley Interdisciplinary Reviews: Climate Change, 6(5), 437-444. https://doi.org/10.1002/wcc.352

\section{Published in:}

Wiley Interdisciplinary Reviews: Climate Change

\section{Document Version:}

Peer reviewed version

Queen's University Belfast - Research Portal:

Link to publication record in Queen's University Belfast Research Portal

\section{Publisher rights}

(C) 2015 Wiley Periodicals, Inc.

This is the peer reviewed version of the following article: Livingstone, D. N. (2015), The climate of war: violence, warfare, and climatic reductionism. WIREs Clim Change, 6: 437-444, which has been published in final form at doi: $10.1002 / w c c .352$. This article may be used for non-commercial purposes in accordance with Wiley Terms and Conditions for Self-Archiving.

\section{General rights}

Copyright for the publications made accessible via the Queen's University Belfast Research Portal is retained by the author(s) and / or other copyright owners and it is a condition of accessing these publications that users recognise and abide by the legal requirements associated with these rights.

Take down policy

The Research Portal is Queen's institutional repository that provides access to Queen's research output. Every effort has been made to ensure that content in the Research Portal does not infringe any person's rights, or applicable UK laws. If you discover content in the Research Portal that you believe breaches copyright or violates any law, please contact openaccess@qub.ac.uk. 
THE CLIMATE OF WAR:

Violence, Warfare and Climatic Reductionism

David N. Livingstone

WIREs Climate Change

\begin{abstract}
National security agencies and other interested parties now often regard conflict as the inevitable consequence of climate change. This inclination to reduce war to the vicissitudes of climate is not new however. Here I examine some of the earlier ways in which violence was attributed to climatic conditions, particularly in the United States, and trace links between these older advocates of climatic determinism and the recent writings of those insisting that climate change will usher in a grim world of chronic warfare. It ends by drawing attention to the writings of some critics who are troubled by the ease with which climatic reductionism is capturing the public imagination.
\end{abstract}

\title{
Key words
}

American Civil War, Arnold Toynbee, climate change, climatic determinism, Ellen Semple, Ellsworth Huntington, John W. Draper, national security, Quincy Wright, Sydney Markham, war.

\section{INTRODUCTION}

'Climate Change will lead to an increased threat of war, violence and military action against the UK and risks reversing the progress of civilisation' ${ }^{1}$ So readers of the Guardian newspaper were told on 6 July 2011, on the authority of Chris Huhne, then Britain's Secretary of State for Energy and Climate Change. In recent years the idea that climate change should be treated as a major player on the world's national security stage has gripped the public imagination, even if, as Halvard Buhaug recently pointed out in the pages of this journal, current 'quantitative research on climate and conflict' has demonstrated that 'the two phenomena are not connected in the simple and direct manner' that is often claimed. ${ }^{2}$ Certainly the idea that climate change breeds conflict is a refrain echoing its way through the recentlypublished book lists, ${ }^{3-5}$ and has featured prominently over the past decade and more in a range of prominent government-orientated reports by political analysts and policy makers. ${ }^{6-8}$ 
In most of these narratives the tragic history of humanity's future is reduced to the vicissitudes of climate's reign. Global warming, we are told, will mean a falling food supply, and that means famine, death and war. Here climate is writing a script that stars Malthus and Hobbes as the leading dramatis personae: exceed the world's climatically-determined carrying capacity and countless millions live a life that's nasty, brutish and short. The result will be a profoundly differentiated world - the fault-line mostly running along a north-south divide - rife with violence and conflict. A sense of necessitarian inevitability weaves it way through many of these scenarios.

Hunting for connections between warfare and climate is not a new pastime, however. To the contrary; it has a long genealogy. Revisiting something of this history, I contend, is illuminating inasmuch as distance enables us to see with particular clarity the ideological investment frequently exhibited by proponents of the idea that war may be reduced to matters of climate. It may also enable us to discern resonances between traditional climatic determinism and contemporary climate change reductionism. By perusing the earlier prosecution of climatic historicism, moreover, the moral components of climate-warfare nexus are exposed with particular clarity. The ways in which some of these earlier advocates of climatic determinism could absolve history of ethical accountability by reducing war to weather invites us to ponder whether a similar anaesthetizing of moral responsibility might not be present amongst some contemporary proponents of climate reductionism.

\section{CLIMATE AND CONFLICT: CONFIGURING CONNECTIONS}

The idea that climate and conflict are causally connected can be traced back at least to Hippocrates' (c. $460 \mathrm{BC}-$ c. $370 \mathrm{BC}$ ) classic treatise on medical topography, On Airs, Waters and Places, which famously asserted that 'the principal reason the Asiatics are more unwarlike ... than the Europeans is the nature of the seasons, which do not undergo any great changes either to heat or cold'. ${ }^{9}$ In Europe, according to the Hippocratics, things were different. Here cowardice gave way to courage, timidity to pugnacity. Why? Because European climates were remarkably variable with hot summers, cold winters, frequent rains and droughts. As Hippocrates explained, 'a climate which is always the same induces indolence, but a 
changeable climate, laborious exertions both of body and mind; and from rest and indolence cowardice is engendered, and from laborious exertions and pains, courage. On this account the inhabitants of Europe are more warlike than the Asiatics' (Ref 9, part 23). The reason, of course, was that climate exerted its influence through the way it brought about an excess or deficiency in the bodily fluids known as the humours - black bile, yellow bile, phlegm and blood - the disposition of which conditioned individual and national temperaments.

The Hippocratic legacy of resorting to climatic humoralism as a means of explaining warfare was deep and lasting, perhaps most famously resurfacing in Montesquieu's L'Esprit des Lois (1748). Here he reported that inhabitants of cold climatic regimes exhibited a 'bravery' signally lacking in the 'inhabitants of warm countries' who were 'timorous'. This circumstance, of course, was directly relevant to the conduct of war. As Montesquieu explained, 'If we reflect on the late wars ... we shall find that the northern people, transplanted into southern regions, did not perform such exploits as their countrymen who, fighting in their own climate, possessed their full vigour and courage'.$^{10}$

I do not propose to follow the twists and turns of that lengthy journey here however; aspects of it have been treated elsewhere. ${ }^{12-14}$ Instead I want to pick up the story in the late nineteenth and early twentieth centuries when climatic determinism reached new heights. Two or three accounts of the American Civil War will be my primary focus, not least because some writings from this period continue to serve as reference points for today's champions of the climate-conflict thesis.

\section{Semple, Draper and the American Civil War}

The spirit, if not the letter, of this tradition, mediated through Montesquieu, manifested itself in the writings of the Kentucky geographer Ellen Churchill Semple (1863-1932). Semple was sure that climate not only modified human physiology, but also governed the 'temperament' and 'energy' of different peoples and thus their 'efficiency' as 'political agents'. ${ }^{15}$ By now, of course, the Hippocratic cosmos was reworked into Darwinian categories. What she called the 'climatic control' of the ecology of human settlement only served to intensify 'the struggle for existence' between human groups (Ref. 15, p. 610). But it delivered the kind of polarized world 
ruptured along a north-south divide only too reminiscent of the geo-humoralists. For Semple was certain that the 'the greatest historical developments belong to the North Temperate Zone' (Ref. 15, p. 611). The destiny of the world's nations was thus written in the naturalized language of zonal climate. 'Nature has fixed the mutual destiny of tropical and temperate zones' not least as 'complementary trade zones', she insisted (Ref. 15, p. 616). Economically this meant that the 'hot zone' acted as supplier to the 'Temperate Zone' which enjoyed 'greater industrial efficiency' (Ref. 15, p. 616).

But climate did not simply stimulate regionally diversified economies; it shaped population geography too. Through the operations of 'natural and artificial selection' the 'warm moist' climate of the Gulf and South Atlantic States, she reported, was now 'attracting back to the congenial habitat of the "black belt"' African-Americans from the Northern states, where 'their numbers are being further depleted by a harsh climate, which finds in them a large proportion of the unfit' (Ref. 15, p. 619). This Darwinian gesture notwithstanding, the Montesquieuean vision persistently reasserted itself. In the Old World the 'influence of climate on race temperament' had dramatically manifested itself. In Europe, 'energetic, provident, serious, thoughtful' northerners stood in marked contrast to the 'southerners of the subtropical Mediterranean basin' whom she portrayed as 'easy-going, improvident ... emotional, imaginative' (Ref. 15, p. 620). It wasn't difficult to transfer such regional portraiture across the Atlantic. 'The divergent development of Northerners and Southerners in America arose from contrasts in climate, soil and area' Semple announced. 'It was not only the enervating heat and moisture of the Southern States, but also the large extent of their fertile area which necessitated slave labor, introduced the plantation system, and resulted in the whole aristocratic organization of society in the South' (Ref. 15, p. 622).

The climatic mindset that Semple here elevated into lofty explanatory principle had long been installed in her geopolitical outlook. She had already applied its reductionist logic to explaining the circumstances that gave rise to the American Civil War in her 1903 American History and its Geographic Conditions. ${ }^{16}$ By causally coupling climatic conditions with agricultural production Semple had a ready-made formula for explaining the sources of a war whose frontier zone ran along 'a climatic 
line' dividing an urban North from a rural South (Ref. 16, p. 346). It was a simple enough equation: history reduced to geography. For what she called 'sectional feeling' had its origins 'in difference of climate and soil' (Ref. 16, 284). To Semple, then, politics followed pedology; slavery was a matter of soil; conflict boiled down to climate. As she explained:

The question of slavery in the United States was primarily a question of climate and soil ... The morale of the institution, like the right of succession, was long a mooted question, until New England, having discovered the economic unfitness of slave industry for her boulder-strewn soil took the lead in the crusade against it. The South, by the same token of geographical conditions, but conditions favorable to the plantation system which along made slave labor profitable, upheld the institution both on economic and moral grounds (Ref. 16, p. 280).

Semple was not the first to deliver a climatic reading of the Civil War however. John William Draper's three-volume History of the American Civil War, which appeared in 1867, had already foregrounded climate as the conflict's explanans par excellence. ${ }^{17}$ Draper (1811-1882), President of New York University from 1850 to 1873 , professor of chemistry, and architect of the so-called 'conflict model' of science and religion, brought a scientist's eye to the task. Right upfront he announced 'the great truth that societies advance in a preordained and inevitable course' on account of 'uncontrollable causes' (Ref. 17, vol. 1, p. iii). And chief among these was climate, a subject that dominated the first volume of his history which was designed to "set forth the causes of the war" (Ref. 17, vol. 1, p. v).

Like Montesquieu, Draper was convinced that climate exercised its global imperial power via human physiology which, in turn, conditioned regional character. It delivered a literal Weltschauung - world-view - suffused with the lingering aftertaste of Renaissance geo-humoralism:

The nations of men are arranged by climate on the surface of the earth in bands that have a most important physiological relation. In the torrid zone, intellectual development does not advance beyond the stage of childhood ... In the warmer 
portions of the temperate zone, the stage of youth and commencing manhood is reached. ... Along the cooler portions of that zone, the character attained is that of individual maturity, staid sobriety of demeanor, reflective habits, tardy action (Ref. 17, vol. 1, pp. 101-102).

For Draper, then, zonal climate, bodily organization and mental character were tightly knitted together. And this coalition, when combined with the direct impact of seasonal variation in different latitudes, translated into distinct economic regimes.

The argument now flowed in predictable channels. Draper wanted his readers to be clear that the 'differentiation' of the American nation 'into two sections ... the free and the slave powers' had been effected 'chiefly through the agency of climate' (Ref. 17, vol. 1, p.20). And this climate-driven disjunction had produced a geopolitical bi-polarity ripe for internecine hostility. 'A self-conscious democracy, animated by ideas of individualism, was the climate issue in the North' he declared; 'an aristocracy, produced by sentiments of personal independence and based upon human slavery, was the climate issue in the South' (Ref. 17, vol. 1, p. 21). It was climate that had 'separated the American nation into two sections'; it was climate that 'had made a North and a South'; it was climate that had cultivated 'the distinctly marked' political instincts of each culture (Ref. 17, vol. 1, p. 361). It could all be captured in a formula approaching a climatic syllogism: 'Climate tendencies facilitate the abolition of slavery in a cold country, but oppose it in one that is warm' (Ref. 17, vol. 1, p. 342). Not surprisingly, in a major section of the book entitled 'Tendency to Antagonism Impressed on the American Population by Climate and Other Causes', Draper highlighted how the climate had produced two cultures intrinsically 'antagonistic' to each other (Ref. 17, vol. 1, p. 243).

It is not difficult to discern the appeal of climatic destinism. It delivered explanatory simplicity, political self-justification, and ethical absolution. For the sense of eschatological inevitability in humanity's following a script written in the main by climate brought with it a sense of moral relief. As Draper put it: 'Now when we appreciate how much the actions of men ... are determined by climate and other natural circumstances, our animosities lose much of their asperity, and the return of kind feelings is hastened' (Ref. 17, vol. 1, p. iii). Climate's actions had the effect of 
freeing political history from the burdens of moral accountability. Naturalizing the causes of the civil war was thus a key means of fostering in the post-bellum era what he called 'more philosophical, more enlarged, more enlightened, and, in truth, more benevolent views of each other's proceedings' (Ref. 17, vol. 1, p. 47). For by displaying to the world how climate had ghost-written different histories in North and South, Draper, as his biographer Donald Fleming put it, 'drew the sting from any moral recrimination'. 'Indeed', Fleming goes on, 'one might suppose that the chief convenience - and possibly the chief defect - of the "climatic" view of history was to by-pass ethical concerns altogether' ${ }^{18}$

\section{Huntington, conflict and climate change}

In elaborating his climatic philosophy of history, it is not surprising that the influential, if maverick, Yale geographer Ellsworth Huntington (1876-1947) would also cast his eye from time to time on the slave question. In his 1915 manifesto, Civilization and Climate, for example, he insisted that in accounting for the contrasts between the northern and southern states, 'climatic effects' were the most 'potent'. 'Slavery,' he judged, 'failed to flourish in the North not because of any moral objection to it, for the most godly Puritans held slaves, but because the climate made it unprofitable'. ${ }^{19}$ What on the surface looked like a question of high moral principle, turned out to a case of low economic pragmatism. Morality was a mere matter of meteorology.

Thirty years later, in 1945, he was still pushing economic climatology as the fundamental reason for the South's underdevelopment. And again the reduction of ethical sentiment to the vagaries of the weather surfaced with renewed vigour. 'The suppression of slavery in the North was not due chiefly to moral conviction' he pronounced. 'That arose after long experience had shown that slavery did not pay in a cool climate'. In the South the weather was different, and so were the racial politics. It was the 'warm, unstimulating weather' that fostered entirely different 'social ideals' south of the Mason-Dixon line. Naturally - or better, naturalistically the South 'favored slavery and attached a social stigma to work with the hands'. So, to Huntington, it was plain for all to see that 'climatic contrasts paved the way for civil war'. ${ }^{20}$ 
Huntington's reading of the American Civil War through the lens of climate was fully in keeping with the outlook of writers like Draper and Semple. But in other ways he moved beyond their rather static climatic historicism by headlining the role that climate change played in the history of conflict and civil unrest. As such he occupies a pivotal position in the transition to more recent anxieties over climate change and violent conflict. What is important though is that, for Huntington, climate and climate-change determinism were all-of-a-piece. In both cases history was driven by the vagaries of climate.

Huntington was long convinced about the evidence for historic climate change, not least from tree-ring analysis, and from as early as 1907, he urged that the climatic 'pulsations' he believed he had detected played a profoundly influential role in human affairs. ${ }^{21}$ And so, in The Pulse of Asia - a work part travelogue, part ethnographic depiction, part geographical description and based on a Carnegiesponsored expedition - he set out to show how 'disorder, wars, and migrations' had arisen in concert with climatic oscillations (Ref. 21, p. 16). Quite simply it was a changing 'climate which almost irresistibly tempts the Arab to be a plunderer as well as a nomad' (Ref. 21, p. 6). But his eye - or what James Rodger Fleming dubs his 'overheated imagination' - strayed into other spatial and temporal zones too (Ref 12, p 97). Europe's 'relapse' during the Dark Ages was on account of 'a rapid change of climate in Asia and probably all over the world' inducing violent 'barbarian' migration (Ref. 21, p. 5). To Huntington, as he scanned the global horizon, this meant there were contemporary lessons to be learned. It all boiled down to one conclusion: 'long-continuing changes of climate have been one of the controlling causes of the rise and fall of the great nations of the world' (Ref. 21, p. 382).

A dominant theme in the Huntington scenario was already now surfacing - the violent political economy of progressive desiccation. Huntington believed he had amassed a large body of data showing that 'during the last two thousand years there has been a widespread and pronounced tendency toward aridity' (Ref. 21, pp. 13-14). With an all-too-eager proclivity for elevating the particular into the universal he promptly outlined a general law: 'In relatively dry regions increasing aridity is a dire calamity, giving rise to famine and distress. These, in turn, are fruitful causes of wars and migrations' (Ref. 21, p. 14). Desiccation had determined the shape of human 
history time and time again by dictating the direction in which the whole narrative moved. The specifics of Chinese Turkestan could stand as proxy for global history and so with the enthusiasm of a new convert who has stumbled upon a universal truth he announced: 'Everywhere in arid regions we find evidence that desiccation has caused famines, depopulation, raids, wars, migrations, and the decay of civilization' (Ref. 21, p. 379).

Huntington returned to the subject in 1926 in The Pulse of Progress, a work which dealt centrally with Jewish history. ${ }^{22}$ Inferential though he admitted his theory to be, Huntington was sure that population movements, invasions, and raids were all attributable to a drying climate. The Libyan and Edomite incursions into Egypt around the first millennium B.C., for example, occurred during a time of 'pronounced aridity' (Ref. 22, p. 130). In China too, the 'half century of increasing aridity from 250 to 200 B.C. was a time of constant invasions on the part of the barbarian nomads of the north and west' (Ref. 22, p. 134). All this pointed to the conclusion that periodic climatic changes needed to be accorded a far more prominent role in historical explanations of violence and war. Later, in support of his thesis he set about correlating Arnold Toynbee's catalogue of 'historic migrations of nomads from the deserts and steppes of Asia and Africa' with cycles of tree ring growth, changing lake levels and the like (Ref. 20, p. 562).

Desiccating climatic regimes of course did not just incite conflicts across territorial frontiers moreover; they also provoked civil unrest. In Turkey, for instance, Huntington urged that the agricultural consequences of increasing aridity meant that local farmers often resisted tax 'officials and their minions' who 'would employ force and extortion' in their efforts to extract dues. Conditions like these could easily breed insurrection, and Huntington was sure that 'many civil commotions' were stimulated by 'the discontent' that prolonged periods of unfavourable weather and poor crops inevitably induced (Ref. 20, p. 224).

\section{Huntington's long shadow}

While Huntington was often disparaged for his tendency to overgeneralise ad libitum, to keep fact rather too subservient to theory, to downplay human agency, and to display a troubling methodological naivety, his influence has continued to linger 
amongst those coupling climate and conflict in causal ways. Arnold Toynbee (18891975), for example, confessed that he had been 'enormously influenced ${ }^{23}$ by Huntington whom he described as 'one of our most distinguished and originalminded students of the physical environment of human life' ${ }^{24}$ He found compelling Huntington's claim that weather conditions drifting from desiccation to humidity provided a convincing explanation of why 'the Mongols erupted on all fronts with an unprecedented vehemence in the thirteenth century' (Ref. 24, vol. 3, p. 440).

In his magnum opus, $A$ Study of War, first published during the second world war in 1942, the American political scientist, Quincy Wright (1890-1970), brother of the celebrated geneticist Sewall Wright, likewise found inspiration in Huntington's thesis. ${ }^{25}$ Besides referring to his work on climatic oscillations, Wright turned to Huntington's World Power and Evolution in support of the direct causal connection between climatic conditions and warlike impulses applying this naturalistic explanation in particular to what he called 'primitive peoples' (Ref. 25, p. 354). It was a general principle: 'a temperate or warm, somewhat variable, and stimulating climate favors warlikeness ... Among contemporary primitive people the largest proportion of the warlike live in hot regions of medium climatic energy' (Ref. 25, p. $63)$.

Huntington-style connections between climate, conflict and energetics likewise captured the imagination of Sir Sydney Frank Markham (1897-1975) British politician, ex-serviceman, and local historian. Markham was obviously in close contact with Huntington for in the preface to his 1942 Climate and the Energy of Nations he thanked him for 'much excellent advice and for undertaking the arduous task of proofreading' ${ }^{26}$ Markham was convinced that the mental and physical 'energy' of different nations was indeed critically dependent on climate. And to substantiate that suspicion he turned his attention to the American South. In his view, Southerners had adapted too fully to the hot climate of the South by developing 'a life-long habit of acting more slowly than the Northerners' - a behavioural trait that had stunted economic growth and retarded social progress (Ref. 26, p. 180). Back in the days of the Civil War the self-same forces had been at work. The North enjoyed 'great climatic advantages' and 'an infinitely greater industrial capacity' which meant that 'the whole economy of the South ... seemed to be at a standstill, whilst the 
bounding, enterprising North went farther ahead' (Ref. 26, p. 163).

Huntington's name could surely be fished out of many climate-related publications in the decades that followed. An exhaustive trawl, while no doubt illuminating, is not my quarry here however. Suffice to record that his work remains an anchor-point for discussions, both scholarly and popular, of climate and conflict. Recent writers, of course, routinely recoil from his judgmental historicist mindset and claim to eschew the racial biases that were woven into the fabric of his understanding of human culture. Nonetheless his name continues to crop up in diagnostic statements on how climate is said to provoke warfare. David Zhang and his colleagues, for example, present his Pulse of Asia as the first record in the 'longstanding scholarly tradition' that showed 'organized armed conflicts and climate change are correlated' ${ }^{27}$ Jeffrey Mazo too, author Climate Conflict (2010), stages Huntington as the 'first modern scholar to develop a coherent theory of environmental factors as a driver of history'. ${ }^{28}$ But comprehensive inventory is not my purpose. It is simply to redraw attention to the lengthy shadow that Huntingtonshaped environmental causation casts over writing on climate and war in many different registers. For in this intellectual genealogy the force lines connecting classical climate determinism with contemporary climate change reductionism are exposed with particular clarity.

\section{DISSENTING VOICES}

The fashion for reducing war to climate has had a remarkable resurgence in recent years stimulated in part by the proclivities of funding agencies and the priorities of national governments. Not least is this the case with national security agencies. As the British Foreign Secretary, Margaret Beckett, put it in 2007 in her presentation to the UN Security Council first-ever debate on the impact of climate change: the consequences of climate change 'reach to the very heart of the security agenda'. ${ }^{39} \mathrm{~A}$ few years earlier in their report to the United States Department of Defense, on abrupt climate change and 'Its implications for United States National Security', Peter Schwartz and Doug Randall insisted that in the near future 'disruption and conflict will be endemic features of life'.$^{30}$ Once the preserve of classical thinkers, Enlightenment philosophers, and turn-of-the-century geo-historians, 'the allure of a 
naïve climatic determinism is now seducing' - in Mike Hulme's words - 'those hardnosed and most unsentimental of people ... the military and their advisors' ${ }^{31}$ And it is seducing other publicists too. Drawing on the neo-Malthusian analyses of Thomas Homer-Dixon, ${ }^{32-34}$ whom he credited with officiating at the marriage of 'militaryconflict studies and the study of the physical environment ${ }^{\prime},{ }^{35}$ Robert Kaplan announced that 'We all must learn to think like Victorians ... Geographical determinists must be seated at the same honored table as liberal humanists' ${ }^{36}$ This reductionist impulse, however, has not met with universal approval.

A team of research ecologists based mostly at Colorado State University, for example, has challenged the suggestion that warming has increased the risk of civil war in Africa. They argue that attributing such causal powers to climate 'oversimplifies systems affected by many geopolitical and social factors'. And they point out that 'unrelated geopolitical trends' - most notably decolonization and the legacy of the Cold War - which 'perturbed the political and social landscape of the African continent' tend to be ignored in climate reductionist agendas. ${ }^{37}$ Halvard Buhaug, a political scientist at the Peace Research Institute Oslo, together with colleagues also have serious reservations about what might be called climatic supremacism. ${ }^{38-40}$ Reworking a range of models used by advocates of climate's determining role in civil wars, Buhaug contends that 'Climate variability is a poor predictor of armed conflict' and that civil wars in Africa are far better explained by such conditions as 'prevalent ethno-political exclusion, poor national economy, and the collapse of the Cold War system'. The prehistory of a particular violent episode is relevant too for, as he puts it, 'recent violence may affect the likelihood of a new conflict breaking out' (Ref. 38, p. 16480).

Empirical inquiries like these, which challenge the assumption that climate and climate change are prime causes of violence, raise troubling concerns about the ease with which an ideology of climate reductionism has infiltrated its way into national security consciousness. ${ }^{41-42}$ Critics of this determinist turn, and particularly of the Malthusian assumption that increased environmental scarcity and migration 'weaken states' and 'cause conflicts and violence,' express grave concerns about the lack of attention devoted to ascertaining the ways that environmental violence reflects or masks other forms of social struggle ${ }^{\prime 43}$ and about the too comfortable 
means by which 'forms of technological engineering ... reduce "solutions" to matters of purely technical concern' ${ }^{44}$ For one thing such scenarios take outbreaks of violence as merely the natural consequence of social-evolutionary adaptation. Climate reductionism thus facilitates the sense that war can be readily 'naturalized and depoliticized' in markedly similar ways to earlier climatic readings of the American Civil War. As one group of researchers observe: 'Some studies in environmental security are in danger of promulgating a modern form of environmental determinism by suggesting that climate conditions directly and dominantly influence the propensity for violence among individuals, communities and states.' When analysts 'neglect the complex political calculus of governance' and the remarkable ways in which human societies actually do cope with challenging environments, they reach 'conclusions that are little different from those ascribing poverty to latitudinal location or lessened individual productivity to hot climates, as was common in European and American scholarship about a century ago' ${ }^{45}$

\section{CONCLUSION}

In his celebrated Walden, first published in 1854, David Henry Thoreau declared 'Our life is frittered away by detail ... Simplify, simplify'. ${ }^{46}$ That dictum, it might be said, has been adopted by many over the centuries who have reduced war to the vagaries of climate. Now it is capturing the imaginations of national security agencies, mass media pundits, and the military. The payoffs of course are considerable. For if war can simply be attributed to the state of nature - to the empire of climate - then, as John William Draper realised a century and a half ago, humanity is well-nigh absolved the responsibility of seeking political solutions to climatic challenges.

\section{ACKNOWLEDGEMENTS}

I am grateful to the Leverhulme Trust for funding this work through the award of a Leverhulme Major Research Fellowship, to the audience at Harvard University where I presented this paper in February 2015, to my colleagues Nuala Johnson, Diarmid Finnegan and Keith Bennett, and to two anonymous reviewers for helpful comments on an earlier version. 


\section{REFERENCES}

1. Climate change will increase threat of war, Chris Huhne to warn. The Guardian, Wednesday 6 July 2011. Available at:

http://www.guardian.co.uk/environment/2011/jul/06/climate-change-war-chrishuhne (accessed 4 April 2015).

2. Buhaug $\mathrm{H}$. Climate-conflict research: some reflections on the way forward. Wiley Interdisciplinary Reviews: Climate Change 2015. Doi: 10.1002/wcc.336.

3. Dyer G. Climate wars: the fight for survival as the world overheats. Oneworld Publications, Oxford, 2010.

4. Welzer H. Climate wars: why people will be killed in the twenty-first century. Polity, Cambridge, 2012.

5. Lee JR. Climate change and armed conflict: hot and cold wars. Routledge, London, 2009.

6. Schwartz P, Randall D. An abrupt climate change scenario and its implications for United States national security. October 2003 Available at:

http://eesc.columbia.edu/courses/v1003/readings/Pentagon.pdf (accessed 4 April 2015).

7. CNA. National security and the threat of climate change. CNA Corporation, Arlington, Va., 2007. Available at http://www.cna.org/reports/climate (accessed 4 April 2015).

8. Campbell KM, Gulledge J. McNeill JR, Podesta J, Ogden P, Fuerth L, Woolsey RJ, Lennon ATJ, Smith J, Weitz R, Mix D. The age of consequences: the foreign policy and national security implications of global climate change. Centre for Strategic and International Studies, and Centre for a New America Security, Washington, D.C., 2007.

9. Hippocrates. On airs, waters and places, translated by Francis Adams, part 16. Available at: http://classics.mit.edu/Hippocrates/airwatpl.1.1.html (accessed 7 April 2015).

10. Montesquieu, Baron de. The spirit of laws. Cosimo, New York, 2011, Book XIV, section 2 .

11. Carey M. Climate and history: a critical review of historical climatology and climate change historiography, Wiley Interdisciplinary Reviews: Climate Change 2012, 3(3): 233-249.

12. Fleming JR. Historical perspectives on climate change. Oxford, NY: Oxford Univ. Press, 1998.

13. Heymann M. The evolution of climate ideas and knowledge, Wiley Interdisciplinary Reviews: Climate Change 2010, 1(4): 581-597.

14. Hulme M. Reducing the Future to Climate: A Story of Climate Determinism and Reductionism, Osiris, 26(1): 245-266. 
15. Semple EC. Influences of geographic environment on the basis of Ratzel's system of anthropo-geography. Henry Holt, New York, 1911, 608.

16. Semple EC. American history and its geographic conditions. Houghton, Mifflin, Boston, 1903.

17. Draper JW. History of the American Civil War, 3 vols. Harper, New York, 1867.

18. Fleming D. John William Draper and the religion of science. University of Pennsylvania Press, Philadelphia, 1950, 119.

19. Huntington E. Civilization and climate. Yale University Press, New Haven, 1915, 22-23.

20. Huntington E. Mainsprings of civilization. Wiley, New York, 1945, 289-290.

21. Huntington E. The pulse of Asia. A journey in Central Asia illustrating the geographic basis of history. Houghton Mifflin, 1907.

22. Huntington $\mathrm{E}$. The pulse of progress including a sketch of Jewish history. Charles Scriber's Sons, New York, 1926.

23. Toynbee AJ. Foreword, in Martin, GJ., Ellsworth Huntington: his life and thought. Archon Books, Hamden, CT., 1973, ix.

24. Toynbee AJ. A study of history. Oxford University Press, Oxford, 1934, vol. 1, 292.

25. Wright $Q, A$ study of war. Second edition, with a commentary on war since 1942. University of Chicago Press, Chicago, 1965.

26. Markham SF. Climate and the energy of nations. Oxford University Press, New York, 1944, x.

27. Zhang DD, Zhang J, Lee HF, He Y-Q. Climate change and war frequency in Eastern China over the last millennium. Human Ecology 2007, 403-414, 403.

28. Mazo J. Climate conflict: how global warming threatens security and what to do about it. Routledge, London, 2010, 37.

39. Testimony of Rt. Hon. Margaret Beckett (Former Secretary of State for Foreign and Commonwealth Affairs of the United Kingdom), before a joint hearing of the House Permanent Select Committee on Intelligence, Subcommittee on Intelligence Community Management, and House Select Committee on Energy Independence and Global Warming, U.S. House of Representatives, Washington, DC, June 24, 2008. Available online at: http://fas.org/irp/congress/2008_hr/062508beckett.pdf (accessed 7 April 2015).

30. Schwartz P and Randall P. An abrupt climate change scenario and its implications for United States national security. October 2003, p. 22. Available online at: http://eesc.columbia.edu/courses/v1003/readings/Pentagon.pdf (accessed 1 July, 2015).

31. Hulme M. Climate security: the new determinism. Open Democracy 20 December 2007. Available online at:

https://www.opendemocracy.net/article/climate_security_the_new_determinism (accessed 1 July, 2015). 
32. Homer-Dixon TF. On the threshold: environmental changes as causes of acute conflict, International Security 1991, 19(2): 76-116.

33. Homer-Dixon TF and Blitt, J. eds. Ecoviolence: links among environment, population, and security. Rowman \& Littlefield, Lanham MD, 1998.

34. Homer-Dixon TF. Environment, Scarcity and Violence. Princeton, NJ: Princeton University Press; 1999.

35. Kaplan RD. The coming anarchy: how scarcity, crime, overpopulation, tribalism, and disease are rapidly destroying the social fabric of our planet. The Atlantic February, 1994: 7, 8. Available online at http://www.theatlantic.com/magazine/archive/1994/02/the-cominganarchy/304670/ (accessed 1 July, 2015).

36. Kaplan, RD. The revenge of geography. Foreign Policy May/June, 2009. Available online at:

http://www3.dogus.edu.tr/cerdem/images/Political\%20Geography/Kaplan\%20Reve nge\%20of\%20Geography.pdf (accessed 1 July, 2015).

37. Sutton AE, Dohn J, Loyd K, Tredennick A, Bucini G, Solórzano A, Prihodko L, and Hanan NP. Does warming increase the risk of civil war in Africa? Proceedings of the National Academy of Sciences June 2010, 107, no. 25: E102.

38. Buhaug $\mathrm{H}, \mathrm{Climate}$ not to blame for African civil wars. Proceedings of the National Academy of Sciences September 2010, 107, no. 38: 16477-16482.

39. Theisen OM, Holtermann $\mathrm{H}$, Buhaug $\mathrm{H}$. Climate wars? Assessing the claim that drought breeds conflict. International Security, Winter 2011/2012, 36: 79-106.

40. Theisen OM, Gleditsch NP, Buhaug $\mathrm{H}$. Is climate change a driver of armed conflict? Climatic Change, 2013, 117: 613-625.

41. Gleditsch NP. Whither the Weather? Climate change and conflict. Journal of Peace Research, 2012, 49: 3-9.

42. Gemenne F, Barnett J, Adger WN, Dabelko GD. Climate and security: evidence, emerging risks, and a new agenda. Climatic Change, 2014, 123: 1-9.

43. Peluso NL, Watts M. Violent environments. In Peluso NL, Watts $M$, ed. Violent environments. Cornell University Press, Ithaca NY, 2001 3-38.

44. Dalby, S. Biopolitics and climate security in the Anthropocene. Geoforum 2013, 49: 184-192, 191.

45. Raleigh C, Linke A, O'Loughlin J. Extreme temperatures and violence. Nature Climate Change 2014, 4: 76-77.

46. Thoreau DH. Walden: with an introduction by Joseph Wood Krutch. Harper \& Brothers, New York, 1950, 119. 